\title{
A Teacher's Diary as a Research Instrument
}

\section{Adriana Wiegerová, Alena Lampertová}

\begin{abstract}
The focus of this paper is the entry to the school practices by novice teachers. Difficulties in the teaching of novice teachers were observed and critical events of the first year in the school environment are described. Critical events are viewed through statements of novice teachers in interviews and in diaries of teachers. Teachers kept diaries throughout the first year in the primary school. The paper offers authentic statements of teachers and analyses problem situations in adaptation of teachers in the school terrain.
\end{abstract}

Key words: novice teacher, critical events, diaries of teachers, adaptation of teachers in the school terrain

\section{Introduction}

One of the options of how to analyse the daily work of a beginning teacher in the praxis is to analyse the teacher's diary. One could say that the teacher's diary is, to a certain extent, a continuation of student-teaching portfolio that was being developed when carrying out the obligatory student teaching as a part of university studies. However, the teacher diary's already provides a real reflection of the school life. It is not a simulation created during student teaching under more ideal conditions. More ideal conditions involve also for example the fact that faculties can choose their own lab schools. The teacher's diary is however a mirror of reality and of what the teacher actually goes 
through in the given moment, in the given situation. The beginning teacher can depict problems as well as joys encountered daily which opens up new possibilities for a further analysis. The diary serves as a "listening friend" for the given subject. An internal dialogue takes place during writing which has an important self-reflective value for the teacher.

The diary opens the door to a secret, unchartered world, to a fragile reality, which is another reason why it stirs interest in educational research. According to the authors Maňák, Š. Švec, V. Švec (ed.), the diary is a "personal document of a subject serving to depict experienced and subjectively perceived situations and events" [3]. It is the subjective experience of a teacher and all events in school that he/she considers to be important and which he/she believes have an impact on him/her that can bring new knowledge in the life of a beginning teacher. Taghilou [4] considers the diary to be the simplest way of targeted reflection of a teacher and his/her reflective instruction. The teacher's diary is used in educational research more sporadically. It is because teachers disclose their internal experiences when writing the diary and the processing of statements is often time demanding. The work on one's own teacher diary, though time demanding, is unquestionably important in terms of the teacher's progress, improvement and analysis of one's own processes of self-evaluation. In other words, it is an investment in one's own improvement. Zeki [5] also emphasised the positive aspects of using a diary in the teaching profession in his works. He argues that the teacher's diary is an important self-regulating strategy. If we thus see the beginning teacher as a "novice" in the school-life reality, then writing a teacher's diary can significantly impact the development of his/her professional competencies. Penso, Shoham, Shiloh [6] emphasise, based on the analysis of their research, that the level of reflection of a beginning teacher is very low. Šimoník equally points out [7] that beginning teachers are not able to undergo objective self-reflection and to evaluate their work. That is why a diary of a beginning teacher can support the development of the mentioned areas. It can also serve as a means of facing excessive emotions that accompany the first steps of a teacher in school. After the end of the working time, only few beginning teachers can "reset" their thinking and not think about what they went through during the day. That is the reason why writing a diary can be a certain instrument of materialising feelings and opinions that are hard to describe in words. To a certain degree, we can thus say that writing a diary can have therapeutic effects as well. The work of a teacher is rich in interactions, especially in the process of primary education, because the beginning teacher is in the position of a class teacher. He/she is in constant contact with students, teaches them, educates them, listens to family stories, monitors the situation in the group of children, deals with ordinary conflicts in group, and oversees the safety of children. Teachers can process their opinions in a diary. These are often more authentic in this form. After some time, the teacher can come back to the given situation. He/ she can then better analyse what happened, how he/she responded and managed to deal with the given situation. 
Writing a teacher's diary is an interesting research instrument. It enables to detect: Process of introduction into the school environment in a fine, sensitive way with unique expression value; Art of work of a beginning and introducing teacher; Dealing with the new environment on the part of the beginning teacher; Work of the teacher body; Habits and stereotypes of the teacher body; School management. Maňák, Š. Švec and V. Švec (ed.) [3] distinguish between two forms of a diary - the structured and non-structured form. The structured diary should contain a clear set of instructions about what and how to write indicating a specific example of what is correct. The subject must exactly know what is expected to be recorded, in what time interval, in what extent and with what purpose. Clarity is ensured if one page covers one period of study - a day, week or month. At the end, several pages should be left for free notes. The non-structured diary on the other hand, unlike the structured one, enables a deeper analysis. A researcher can find implications that could not be found in a structured diary. Considering the great number of subjects, it is however more time demanding to process. Another positive aspect is that it creates a more open atmosphere, because subjects of research know what the researcher is examining. The written statements of subjects are free and the scope of statements does not have to be limited, unless the nature of research requires it. Based on the research results that we are currently analysing [9] we believe that we can talk also of another form of diary processing, which is the combined form. As the name suggests, it is a certain combination of the above-mentioned forms. When creating such a form of diary, it is possible to put down the feelings and opinions in an unstructured way first. Based on these, concept categories can be developed with more structured lines. Such a process or working with the combined diary provides researchers with initial freedom when carrying out the research, when searching for various implications and meanings. It consequently enables more precise specification and focusing on the examined phenomena and their deeper analysis. Naturally, working with the combined diary requires focused cooperation of the researcher and the subject of research.

From the aspect of the educational research it is necessary to describe the positive and negative aspects of applications of such developed research instrument.

Advantages of working with a diary include the following:

- It enables to describe situations that are harder to handle in person;

- The subject can come back later to his/her statements later (the subject can e.g. add something later);

- It has therapeutic effects;

- It enables reflection of one's own work;

- It minimises the feeling of the subject that research is involved;

- It creates better conditions for preventing distortion of statements, since they are recorded by the subject him/herself; 
- The subject him/herself can decide when the diary is to be written and how much time will be devoted to it;

- The subject can choose the form in which he/she will write the diary - electronic, written.

The following can be considered as disadvantages:

- Demanding attracting of subjects for research sample (due to the length of research, time required for frequent writing);

- From the aspect of participating subjects recording their ideas instead of an interview which is shorter;

- Possible briefness in writing in case of non-structured form of diary;

- Possible complexity, disputability in the interpretation of the acquired data.

The possible disputability in the interpretation of the acquired data can be prevented if the researcher applies also other methods and techniques apart from the diary. That way, the acquired data gain completeness and provide clearer findings.

In the following part we plan to introduce some experience from our own research to our readers that we started to perform in September 2011. The fundamental pillar of our research efforts was the fact that we wanted to find out how teachers feel when starting their first job - what they experience at school.

Before using the diary method, we conducted unstructured interviews with teachers and it was the first phase of the research. Already during them the categories started to crystallise that we focused on later. After the interviews we asked the teachers to start writing their own diary. It was not easy to persuade the colleagues to perform this type of data collection. Since processing of the diary by a teacher is a demanding and mainly a lengthy process. The person that decides to provide their own remarks by means of a diary must have confidence in you.

In the second phase of the research each teacher was asked to write their first feelings, experiences that they remembered from the first month at school. The task was as follows: "Describe how was your first month at school in the position of a teacher beginner." This phase of processing the diary had an unstructured form.

We started the data collection by means of a diary as of the first week in October 2011. However, a person's perception of the same situation may change over the time. Right due to this reason it was necessary to capture emotions, experiences, thinking and initial experience of a teacher beginner from the course of events at school.

In the period from the start of October to January 2012 the teachers completed their diaries every week in an unstructured form. Their task was to write down everything that they considered being important from their point of view. Right upon this continuous analysis the categories gradually start to show, which are interesting for 
the research. We would like to share data processing from this phase of the research with our readers.

\section{Preparation of the teacher}

One of the teachers said during the unofficial interviews during September that she does not write preparations in the same way as she used to do during her university studies. However, in October she said the following: "I started to write preparations during the weekend for the following two weeks; it takes half a day but then the whole week is excellent and everything is alright and without any unnecessary chaos." After less than one month she gradually realises the importance of preparation. However, the question is what they actually mean under preparation. In the picture (Figure 1) we can see a certain example of preparation for one day. The teacher considers the contents of the day to be important; specifically she focused on Slovak language. But certainly it was not the only subject that they had at that time.

Figure 1

Preparation for the lesson

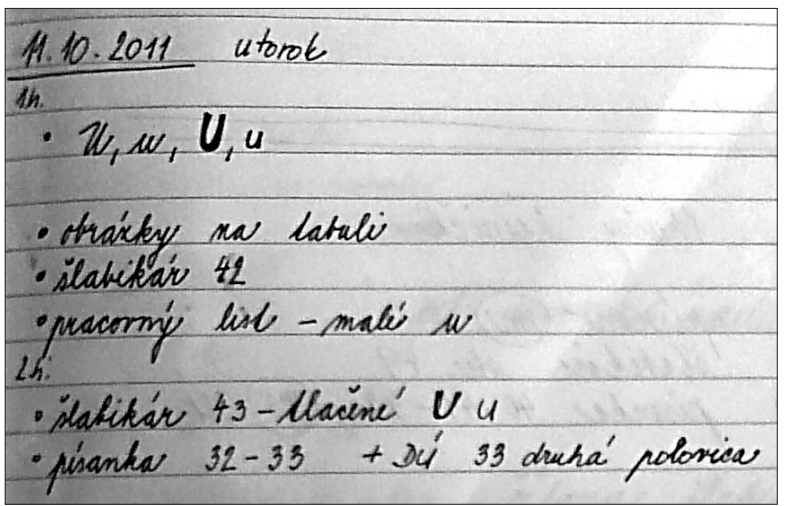




\section{Knowledge of the school as an organisation}

Another category includes the process of gaining knowledge of the school and its operation. One of the teachers stated during the second week of October: "I still cannot get used to supervision on the corridor" (Figure 2). Other records were rather related to the completion of class books while several of them faced a conflict between what they expected and reality. However, in their case there was no "shock from reality" as stated by Veenman (1998). "I expected that we will make plans together but very soon I realised how wrong I was."

In the following statement we can see the contrast between what the teacher wanted and what she actually does. "It is the end of October and we started to complete the class book, whereas I am not writing what l am doing right now but what is in my plans. I got into a slightly vicious circle that I cannot affect and I shall keep spinning in it during the whole year; however, the moral of it for me is that during the holidays I am surely going to prepare plans for my class processed only by me." At the end she expressed her desire for change and for remedy. In another case the class book and the qualification list was submitted but the materials to derive from were missing. "During the first two weeks I got the class book and the qualification list but the issue for me was that I still did not see any plans or curriculums or similar matters."

Figure 2

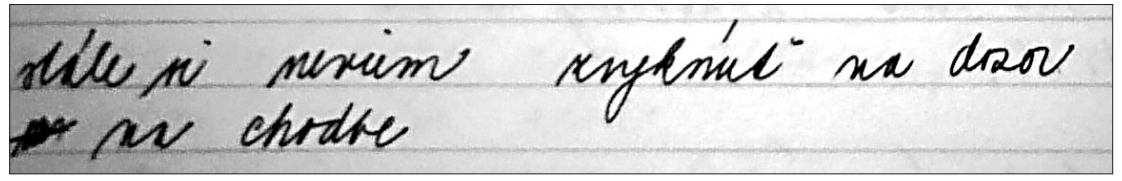

\section{Cooperation with parents}

Teachers' work is constantly under control in a certain way. It is an extremely demanding process when the teachers think about what the environment thinks about them and how they shall look in the eyes of others. Parents represent a significant feedback for the work of a teacher. The teacher seeks certainties to support their conviction that they chose the right job and that he/she is a good teacher.

The following lines demonstrate this matter. "A mother wrote to me that her daughter is sick and will not come until Wednesday and I wrote back to her to let the child undergo medical treatment and I am also going to the doctor tomorrow. And then she wrote back to me that if I am going to be sick the entire week then she would rather leave her at home (:) ha ha ... this is a compliment. (-)" 
Communication with parents through electronic post is a source of good feelings from one's own work. One of the teachers stated a concrete problem that appeared with the following continuation. "There was a fight of seven boys in the class (due to a game of dogs on the 'carpet' during the big break. We were in the classroom as it was raining outside. I wrote a note to all the seven of them - He was fighting with his classmates during the big break." After reading the note, the parent of one of the pupils became angry and wrote a mail to the teacher. It was described in the diary as follows: "the father does not understand why I wrote a note and I should use other punishment and he wants to meet me." (Figure No. 3) The problem was resolved in a personal meeting. In this case communication through internet is useless since it became another source of stress for the teacher.

Figure 3

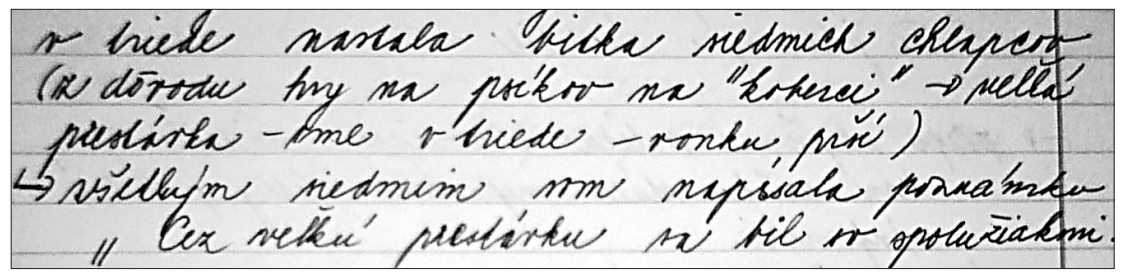

\section{Cooperation with the lead-in teacher}

The relation between a teacher beginner and a lead-in teacher is extremely important in the process of adaptation education. Some teachers are lucky and they can approach their lead-in teacher with their troubles without any problems, as for example in this case: "this week I must inquire what exactly we are going to deal with because I do not understand some of the topics in the time and thematic plans and so I have to ask the lead-in teacher what to do and how."

However, sometimes it happens that the two players in the process of education do not fully realise their tasks that result from this relation. Then the teacher beginner feels that they were not provided all the information according to their ideas and another needless problem might appear. The following lines interpret a similar case: "The timetable makes me angry - I did not know that I can amend it during September according to my needs - the lead-in teacher did not tell me anything about it." However, after some time partial remedy may come about. "Improvement in the relation with the lead-in teacher but she still does not provide me with all the necessary information" (Figure 4). 
Figure 4

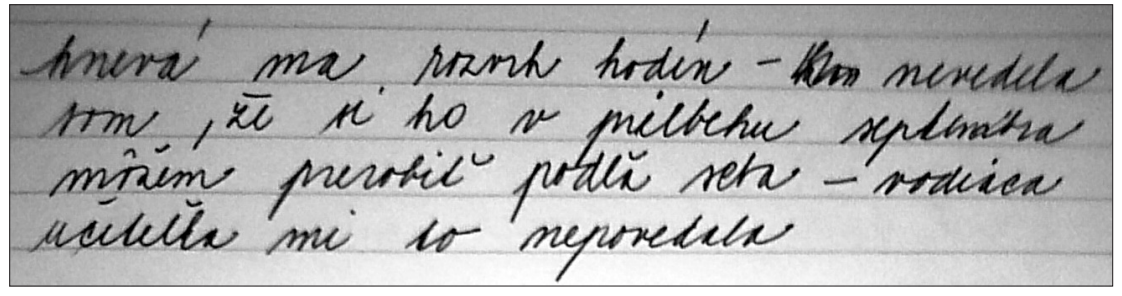

Currently the research is in the third phase. The stage of the unstructured data collection has finished and the basic categories for are being formed for their further shaping. This time the teachers shall process their remarks in the categories formed by us.

From the viewpoint of the second phase of the research we can describe some effects of the process how the teacher beginners establish themselves at the school. They blend together with the individual statements in the diaries. The processes in question are the following:

- doubts (about themselves, about colleagues - comparison),

- seeking certainties (through feedback)

- effort to meet subjective expectations.

Analysis of the first year of the teacher beginner's at work could bring several interesting findings. Last but not least it could point out to what should be avoided already during the university studies so that then the students and the future teachers face less problem situations and so that the university prepares them for their future job in a better quality.

Writing a diary by a beginning teacher could become an obligatory part of the process of introduction during the adaptation training in order to achieve targeted improvement of self-reflective competencies. However this could lead to a loss of openness on the part of the monitored subject. Beginning teachers could adjust the written data in their fear about who the readers of their diary can be. I therefore point out that the teacher's diary should become neither an instrument of legislative aid nor of formal strategies of life-long education. The applicability of the diary always depends on the purpose it is supposed to serve. Internet blogs or websites are currently used as new forms of diary. A diary of a beginning teacher brings new knowledge. It opens possibilities to see the "internal experiences" of a teacher, enables to analyse the school environment and last but not least supplements the whole range of research instruments in education-oriented research. 


\section{References}

Korthagen, F., Kessels J., Koster, B. Lagerwert, B., Wubbels, T. (2012). Jak spojit praxi s teorii: Didaktika realistického vzdélávání učitelü. Brno: Paido.

Penso, S., Shoham, E., \& Shiloah, N. (2001). First Steps in Novice Teachers' Reflective Activity. Teacher Development, 5, 3, 323-338.

Taghilou, M. R. (2007). From reflective teaching to effective learning: A new class order. In Iranian Journal of Language Studies (IJLS) [online]. 1 (2), [cit. 2011-11-16]. Retrieved from:<http:// www.eltanet.org/Kamil'spaper.pdf> elSSN: 2157-4901

Veenman, S. et al. (1998). Evaluation of a Coaching Programme for Mentors of Beginning Teachers. In Professional Development in Education [online]. 24: 3, 41143 [cit. 2011-04-23]. Retrieved from: <1 http://dx.doi.org/10.1080/13674589800200061>.

Zeki, A. (2009). The Effects of Diaries on Self-Regulation Strategies of Preservice Science Teachers. International Journal of Environmental and Science Education [online]. 2010, vol. 5, no. 1, [cit. 16. 11. 2011]. pp. 85-103. Retrieved from: <http://www.eric.ed.gov/PDFS/EJ884413.pdf>. ISSN 1306-3065.

\section{Contact:}

doc. PaedDr. Adriana Wiegerová, PhD.

Mgr. Alena Lampertová

Faculty of Humanities

Tomáš Bat’a University

Mostní 5139

CZ-760 01 Zlín

E-mail:wiegerova@fhs.utb.cz 